\title{
Sekolah Alam di Kalsel; Latar Belakang, Ekspektasi dan Persepsi
}

\author{
Willy Ramadan \\ Universitas Islam Negeri Antasari Banjarmasin, Indonesia \\ willyramadan@uin-antasari.ac.id
}

DOI: $10.18860 /$ mad.v12i1.7656

Abstract. This study aims to identify the background, expectations and perceptions of parents sending their children to SD Alam Muhammadiyah and students in attending education at the Nature School The method in this research is qualitative with a case study approach.. Data collection techniques in this study through interviews, observation, documentation and field notes. The results of this study found that the background that influenced parents decided to send their children to SD Alam can be concluded for several reasons, namely Distrust, Past Experience, Word of Mouth Communication, External Communications, Personal Need and Institutional. While the background of school students in SD Alam is due to the reasons for the Parent Need and School Environment. The expectations of parents is that children have a strong religious foundation. Children have social intelligence, children have good morals / characters, have abilities in sports, schools can direct children to have their own unique and creative talents, supply of available books and the construction of SMP and SMA Alam. Whereas students 'expectations, namely extracurricular programs, are reproduced and students' self-development programs are more often implemented. In the aspect of parental perception is the concept of nature-based schools that are fun and interesting for children, the portion of religious education is more, the rules are more flexible than state schools, prioritizing religious values, character and creativity and do not distinguish between social status and condition of children. While the perception of children is school, teachers and subjects are fun and many extracurricular.

Keyword. Nature School; Expectation; Perception

Abstrak. Penelitian ini bertujuan untuk mengidentifikasi gambaran latar belakang, ekspektasi dan persepsi orangtua menyekolahkan anaknya di SD Alam Muhammadiyah dan peserta didik dalam mengikuti pendidikan di Sekolah Alam. Metode dalam penelitian ini adalah kualitatif dengan pendekatan studi kasus. Teknik pengumpulan data pada penelitian ini melalui wawancara, observasi, dokumentasi dan catatan lapangan. Adapun hasil penelitian ini menemukan bahwa latar belakang yang mempengaruhi orangtua memutuskan untuk menyekolahkan anaknya di SD Alam dapat disimpulkan karena beberapa alasan yaitu Distrust, Past Experience, Word of Mouth Communicationts, External Communications, Personal Need dan Institutional. Sedangkan latar belakang peserta didik sekolah di SD Alam karena alasan Parent Need dan School Environment. Adapun ekspektasi orangtua adalah Anak memiliki pondasi agama yang kuat. Anak memiliki kecerdasan sosial, Anak memilki moral/karakter/akhlak yang baik, memiliki kemampuan dalam olahraga, sekolah bisa mengarahkan anak memiliki bakat tersendiri dan kreatif, suplai buku yang tersedia dan dibangunnya SMP dan SMA Alam. Sedangkan eksepektasi peserta didik yaitu program ekstrakurikuler diperbanyak dan program pengembangan kemandirian siswa lebih sering dilaksanakan. Pada aspek persepsi orangtua adalah konsep sekolah berbasis alam yang menyenangkan dan menarik untuk anak, porsi pendidikan agama lebih banyak, peraturan lebih fleksibel dibanding sekolah negeri, mengutamakan nilai agama, karakter dan kreatifitas dan tidak membedakan status sosial dan kondisi anak. Sedangkan persepsi anak ialah sekolah, guru dan mata pelajarannya menyenangkan dan banyak ekstrakurikuler.

Kata Kunci. Sekolah Alam; Ekspektasi; Persepsi

Received : 03-10-2019

Approved : 27-12-2019

Revised : 26-12-2019

Published : 31-12-2019

Vol. 12 No. 1 Desember 2019

Madrasah homepage: http://ejournal.uin-malang.ac.id/index.php/madrasah/index 


\section{MADRASAH}

Jurnal Pendidikan dan Pembelajaran Dasar

p ISSN: 1979-5599 | e ISSN: 2502-194X

Page | 41

Copyright (C Madrasah Jurnal Pendidikan dan Pembelajaran Dasar. All Right Reserved.

This is an open access article under the CC BY-NC-ND license

(http:// creativecommons.org/licenses/by-nc-nd/4.0/).

Correspondence Address: willyramadan@uin-antasari.ac.id

\section{A. PENDAHULUAN}

Orangtua dan keluarga mempunyai peranan paling penting dan paling berpengaruh dalam melakukan proses parenting terhadap anak. Oleh karena itu, wajar jika setiap orangtua ingin agar kelak anak mereka menjadi manusia yang terdidik dan berkarakter serta mampu menjadi manusia seutuhnya. Untuk mencapai hal itu, orangtua dengan sepenuh hati memberikan dan memilih pendidikan terbaik untuk anak mereka. Apalagi, seiring perkembangan jaman dan semakin bebasnya arus pergaulan, mengakibatkan kecemasan (anxiety) orangtua semakin besar. Sehingga, orangtua sangat berhati-hati dalam memilih lembaga pendidikan untuk buah hati mereka. Hal yang sering menjadi pertimbangan diantaranya adalah kualitas guru, lingkungan, pelajaran bahkan metode dan proses pembelajaran.

Hal ini tidak mengherankan jika ada orangtua yang rela merogoh dana besar untuk memberikan pendidikan untuk anaknya, dengan harapan sang anak mendapatkan pendidikan dan pengajaran terbaik untuk masa depan mereka. Namun, pendidikan di Indonesia dewasa ini dianggap masih banyak mengalami masalah. Elfindri (2012;4) menjelaskan bahwa ukuran pendidikan saat ini hanya berorientasi pada pencapaian kognitif (cognitif achievement), seperti pandangan bahwa pendidikan adalah untuk meningkatkan ilmu, dan faktanya itulah yang mendominasi mind perspective kebanyakan masyarakat indonesia dalam memandang pendidikan.

Maryati dalam Abdul Basir \& Willy Ramadan (2017:1-2) juga menyampaikan bahwa problem pendidikan di Indonesia saat ini terdapatnya kesenjangan yang cukup lebar antara pengetahuan yang dimiliki siswa dengan sikap dan perilakunya. Secara umum, profil pendidikan di Indonesia masih memiliki karakteristik yang tekstual, berorientasi ke produk dan mengabaikan proses. Berorientasi pada IQ tanpa menyentuh EQ (Emosional Quotient), CQ (Creativity Quotient), SQ (Spiritual Quotient dan lebihlebih kearah AQ (Adversity Quotient). Pendidikan kita sekarang juga bersifat school oriented, dalam arti pendidikan hanya untuk melanjutkan sekolah. Sehingga output disiapkan hanya untuk ready to work, bukan ready to use. Pendidikan seperti memiliki makna untuk menghadapi masa depan yang lebih bagus. Pendidikan, menurutnya, masih membelenggu, belum membebaskan dan menyenangkan. Fakta inilah yang disampaikan oleh Adilistiono dalam Iin Purnamasari (2017;29) bahwa berbagai pengalaman kurang baik yang dialami orangtua sebagai kegagalan dalam menjalankan pendidikan di sekolah dengan beragam kasus pada anaknya, tidak dapat dipungkiri sudah melahirkan penilaian dan persepsi negatif serta ketidakpercayaan terhadap sekolah-sekolah formal. Sehingga banyak orangtua yang mencari pendidikan alternatif untuk anaknya, seperti Homeschooling. Sekolah dinilai menjadi lembaga pendidikan yang tidak adil dalam melayani kebutuhan belajar anak, tidak memahami keunikan anak, bahkan sampai pada pandangan bahwa sekolah telah gagal dalam menjalankan peran sebagai lembaga pendidikan. 
Namun demi menjawab kebutuhan tersebut, para pelaku pendidikan baik teoritisi atau praktisi pendidikan terus melakukan evaluasi dan inovasi di dalam dunia pendidikan saat ini, yang kemudian menemukan dan mengembangkan suatu model pendekatan pembelajaran pendidikan dengan dikembangkannya pendekatan tematik. Yaitu suatu model pembelajaran terpadu yang dalam pembelajarannya secara sengaja mengaitkan beberapa aspek baik itu dalam intra mata pelajaran maupun antar mata pelajaran. Pendekatan ini merupakan suatu upaya untuk mengintegrasikan pengetahuan, kemahiran dan nilai pembelajaran serta pemikiran yang kreatif dengan mengunakan tema. Pendekatan tematik ini kemudian diterapkan oleh beberapa sekolah alam, yakni sekolah yang berbasis pada alam lingkungan sekitar sebagai objek belajar. Pembelajaran jenis ini, integratif atau terpadu, menurut John Dewey, merupakan pendekatan untuk mengembangkan pengetahuan siswa dalam pembentukan pengetahuan mereka berdasarkan interaksi antara lingkungan dan pengalaman hidup mereka (Abdullah Hadziq, 2016).

Menurut Poedjiati dalam Maryati (2017;180), diantara cara yang dapat memudahkan anak didik dalam menikmati proses belajar adalah dengan mengaitkan mata pelajaran dengan berbagai macam masalah aktual yang ada di lingkungan sekitar anak. Menurutnya, cara ini akan sangat membantu anak didik yang memiliki tingkat kecerdasannya normal, bahkan yang dibawah rata-rata sekalipun akan mudah pula menangkap berbagai konsep yang akan disajikan oleh pendidik. Karena bagi anak yang cerdas, mereka bisa menerima konsep-konsep yang disampaikan pendidik secara abstrak. Namun tidak demikian bagi mereka yang kecerdasannya biasa-biasa saja atau bahkan yang dibawah normal.

Di Indonesia, Sekolah Alam menjadi pilihan alternatif pendidikan yang dipilih orangtua untuk anak mereka. Begitu juga yang terjadi di Provinsi Kalimantan Selatan, sejak berdiri pada tahu 2012, Sekolah Dasar Alam Muhammadiyah Banjarbaru sebagai pendidikan sekolah dasar pertama yang berbasis alam di Kalimantan Selatan, menawarkan kondisi dan proses pembelajaran yang sangat berbeda dengan sekolahsekolah formal pada umumnya, dan posisinya cukup menunjukan respon yang tinggi dari tahun ke tahun. Ini terlihat dari data penelitian awal yang peneliti dapatkan bahwa pada tahun 2017 siswa secara kesulurahan berjumlah 225, dan pada tahun 2018 siswa sudah berjumlah 292, bahkan setiap kelas sudah dibagi menjadi dua kelas. Menariknya, menurut pengakuan salah seorang guru, bahwa mereka sudah mengantongi nama-nama siswa yang mendaftar untuk tahun 2019 yang sering melebihi kouta dan terpaksa membatasi jumlah pendaftar peserta didik. (Penelitian ini dilakukan pada tahun 2018).

Adapun kaitannya dengan pendidikan di Indonesia, tentu ini menjadi signal, bahwa pendidikan dengan metode atau pendekatan ini menjadi satu fenomena yang cukup memiliki daya pikat yang kuat. Ini terbukti sejak diresmikannya SD Alam ini, semakin banyak orangtua yang mempercayakan anaknya dari tahun ke tahun. Fakta ini tentu punya alasan yang mendasarinya atau faktor-faktor yang melatarbelakanginya. Orangtua memilih sekolah juga tentu mempunyai harapan atau ekspektasi terhadap sekolah tersebut. Diantara hal-hal yang mempengaruhi atau melatarbelakangi ekspektasi seseorang adalah Enduring Service Intensifiers, Personal Need, Transitory Service Intensifiers, Perceived Service Alternatives, Self-Perceived Service Role, Situational Factor, Explicit Service Promise, Implicit Service Promise, World of Mouth and Past Experience (Zeithaml, Berry, \& Parasuraman, 1993). Sehingga, dari latar belakang itu pulalah peneliti menjadi sangat tertarik untuk mengetahui dan meneliti kasus ini. Apa yang menjadi latar belakang 


\section{MADRASAH}

Jurnal Pendidikan dan Pembelajaran Dasar

p ISSN: 1979-5599 | e ISSN: 2502-194X

Page | 43

orangtua sehingga mereka lebih memilih sekolah alam untuk anaknya ketimbang sekolah formal lain, begitu juga persepsi dan ekspektasi baik dari sisi orangtua dan murid terhadap Sekolah Alam ini. Inilah kemudian yang menjadi pijakan peneliti untuk melakukan penelitian ini.

\section{B. METODE PENELITIAN}

Metode dalam penelitian ini adalah kualitatif dengan pendekatan studi kasus, yang memungkinkan peneliti untuk memahami dan menelaah sebuah "kasus" tertentu yang dialami oleh subjek penelitian secara mendalam dan menyeluruh. Kasus tersebut dapat berupa entitas yang konkret, misalnya individu, kelompok kecil, organisasi atau kemitraan (John W. Creswell, 2013). Alasan dipilih pendekatan ini karena peneliti akan memahami dan meneliti aktifitas-aktifitas kelompok manusia yang berkaitan latar belakang pada orangtua dan peserta didik dalam memilih Sekolah Dasar Alam Muhammadiyah sebagai lembaga pendidikannya dan menunjukkan peningkatan setiap tahunnya serta ekspektasi dan persepsi mereka. Penelitian ini mengambil tempat di Sekolah Dasar Alam Muhammadiyah Banjarbaru. Adapun lokasi penelitian ini adalah Jl. Golf Swargaloka RT12 RW03, kel.Syamsuddin Noor, Kec. Landasan Ulin, Kota Banjarbaru. Dalam penelitian ini data akan diperoleh dari sumber yang dapat memberikan informasi yang tentu sesuai dengan tujuan-tujuan penelitian. Adapun tekhnik pengambilan subjek atau informan dalam penelitian ini mengunakan tekhnik snowball sampling sebanyak 10 subjek yaitu 5 Orangtua dan 5 peserta didik yang mengikuti proses pendidikan di Sekolah Alam. Adapun untuk memperoleh data maka teknik pengumpulan data pada penelitian ini melalui wawancara, observasi, dokumentasi dan catatan lapangan. Analisis data dalam penelitian kualitatif dilakukan sejak sebelum peneliti memasuki lapangan, selama dilapangan, dan juga setelah selesai di lapangan. Analisis data ini lebih difokuskan selama proses di lapangan bersamaan dengan pengumpulan data (Sugiyono, 2013). Analisis data dalam penelitian ini mengunakan teknik analisis data kualitatif menurut Miles dan Hubeman, yaitu: Data Reduction (Reduksi Data), Data Display (Penyajian Data), Conclusion Drawing/Verification.

\section{HASIL DAN PEMBAHASAN}

\section{Hasil Penelitian}

\section{a. Latar Belakang, Ekspektasi \& Persepsi Orangtua terhadap Sekolah Alam Muhamadiyah Banjarbaru}

Untuk mengetahui latar belakang, ekspektasi dan persepsi orangtua dalam memutuskan untuk menyekolahkan anaknya di Sekolah Alam Muhammadiyah Banjarbaru, peneliti menggunakan 5 subjek. Subjek yang dimaksud adalah orangtua yang telah menyekolahkan anaknnya di SD Alam Muhammadiyah dan peserta didik yang mengenyam pendidikan di Sekolah Dasar Alam Muhammadiyah. Namun, untuk menjaga kerahasiaan subjek, peneliti tidak menggunakan nama sebenarnya. Adapun hasil wawancara dan observasi pada masing-masing subjek bisa dijelaskan sebagai berikut:

1) Subjek Pertama, subjek pertamakali mengetahui tentang Sekolah Alam melalui Internet. Karena diakhir tahun anaknya meyelesaikan PAUD (Pendidikan Anak Usia Dini), subjek mencari referensi dan membandingkan tentang sekolah-sekolah yang 
tepat untuk buah hatinya melalui website. Baik itu terkait dengan bugdeting, lingkungan, kurikulum dan lokasi sekolah. Infromasi tentang sekolah alam menurutnya tepat untuk anaknya, sebab kurikulum dan lingkungan yang ditawarkan oleh Sekolah Alam cocok untuk anak mereka yang cendrung aktif. Selain melalui internet, subjek juga mencari informasi dan konfirmasi dengan tetangga yang kebetulan sudah menempatkan anaknya di Sekolah Alam. Informasi yang didapat melalui tetangga tentang Sekolah Alam sangat positif dan baik. Dijelaskan bahwa anak-anak tidak melulu belajar di dalam kelas atau ruangan, mereka juga sering belajar di luar kelas (outing class). Sebab, menurutnya ketertarikan anak seusia tersebut masih didominasi oleh dunia bermain dengan teman-teman sejawatnya. Buktinya, diakui oleh subjek bahwa sejak anaknya sekolah di Sekolah Alam, meski belajar sepanjang hari, terbukti saat sampai dirumah anaknya sama sekali tidak menunjukkan kelelahan. Bahkan anaknya terlihat terus semangat dalam belajar. Dengan menyekolahkan anaknya di SD Alam, subjek sangat mengharapkan anaknya bisa bergaul dengan baik, bisa memasyarakat dan memiliki kepribadian yang kuat. Subjek juga mengatakan bahwa selain berakhlak, anak diharapkan bisa membentengi dirinya dengan ilmu-ilmu agama serta punya karakter yang baik. Adapun persepsi subjek mengenai sekolah alam, menurutnya, sesuai namanya merupakan sekolah yang sangat maching dengan kondisi anak, anak-anak dalam proses pembelajaran diajak untuk mengeksplore alam.

2) Subjek Kedua, subjek mengetahui SD Alam pertama kali melalui tetangga. Informasi yang didapat pertama kali adalah bahwa di Sekolah Alam terdapat program Tahfizh, pendidikan Sholat dhuha dan para guru mengajar tidak dengan cara kekerasan. Harapan subjek si buah hati menjadi anak yang sholeh dan berakhlak baik. Secara kelembagaan subjek sangat berharap akan dibangun SMP \& SMA Alam. Konsep Alam yang ditampilkan oleh SD Alam menurut subjek adalah konsep pendidikan yang menarik. Pendidikan di SD Alam lebih banyak porsinya dalam memberikan pendidikan agama di banding lembaga-lembaga pendidikan negeri. Sekolah juga menurutnya tidak membatasi orangtua untuk memantau anak, selama tidak menganggu proses belajar mengajar. Mengingat subjek memiliki anak yang "istimewa", sehingga menurutnya itu sangat membantu proses tumbuh kembang anak. Mengutamakan pembentukan moralitas dan kreatifitas yang dikembangkan juga menjadi nilai tambah bagi subjek.

3) Subjek Ketiga, berbeda halnya dengan subjek ketiga. Mengetahui SD Alam justru karena suami subjek aktif di Organisasi Muhammadiyah dan kedekatan dengan pengelola sekolah. Jadi, selain memang kepercayaan secara kelembagaan terhadap lembaga lembaga pendidikan yang dikelola Muhammadiyah, subjek memutuskan untuk menyekolahkan anaknya di Sekolah Alam cendrung karena alasan pertimbangan psikologi perkembangan anak. Menurutnya, Sekolah Alam tepat untuk psikologi anak yang masih cendrung suka bermain. Harapan subjek anaknya memiliki kreatifitas, cerdas, memiliki sifat kesetiakawanan dan punya keahlian dalam bidang olahraga (Panahan). Sedangkan ke lembaga subjek berharap suplai atau stok buku yang kadang masih sering kosong dan menunggu datang. Sekolah Alam, menurutnya, memiliki peraturan yang cendrung lebih fleksibel dan tidak terlalu ketat, dimana membuat anak enjoy dalam proses belajar mengajar, walaupun tetap memiliki aturan dan kedisiplinan. Sekolah Alam lebih banyak memberikan porsi dalam pendidikan agama dibanding sekolah negeri lain. Menurutnya, konsep 


\section{MADRASAH}

Jurnal Pendidikan dan Pembelajaran Dasar

p ISSN: 1979-5599 | e ISSN: 2502-194X

Page $\mid 45$

berbasis alam di sekolah alam juga merupakan suatu konsep yang baik untuk anak, seperti diajarkan menanam (gardening). Sekolah Alam juga menanamkan nilai-nilai kemandiriannya dan tidak membeda-bedakan status anak (normal atapun ABK)

4) Subjek Keempat, karena subjek ikut suami bertugas di luar kota (Papua), sehingga internet adalah media pilihan yang pertama kali memberikan informasi kepada subjek tentang sekolah alam, walaupun kemudian subjek melakukan cross-check langsung ke sekolah sebelum memutuskan. Subjek memiliki anak yang "istimewa" atau ABK, sehingga membuat subjek harus mencari banyak referensi tentang lembaga pendidikan yang tepat untuk anaknya dan menurutnya Sekolah Alam adalah konsep pendidikan yang sesuai dengan kebutuhan dan kondisi anak. Subjek juga mengakui bahwa, pengalaman tetangga dan keluarga yang memiliki anak "istimewa" yang sama, namun sering dibully di sekolah-sekolah negeri. Sehingga menuntut subjek harus lebih hati-hati memilih lembaga pendidikan untuk buah hatinya. Harapan subjek SD Alam mampu membimbing anaknya untuk memiliki bakat dan kemampuan tersendiri, tidak kalah dengan anak normal yang lain. Selain itu, karena anak subjek cendrung pendiam, sehingga sangat berharap anaknya punya kemampuan sosial yang lebih baik dan terpenting adalah menjadi anak yang taat dalam beragama. Secara kelembagaan subjek sangat berharap akan dibangun SMP \& SMA Alam, agar kemudian mudah untuk subjek memiliha lembaga pendidikan untuk anak. Selain itu, menurutnya, Sekolah Alam memiliki konsep yang cendrung membuat anak lebih nyaman belajar, bahagia dan tidak stress dengan banyak tugas. Sekolah Alam juga sangat mengedepankan pendidikan agama, akhlak/moral, dan kreatifitas.

5) Subjek Kelima, dalam penjelesannya subjek menyampaikan bahwa mengetahui Sekolah Alam dari keluarga (kaka ipar). Informasi yang didapat, sekolah alam sangat mengutamakan pendidikan agama dan sistem proses belajar mengajarnya sangat nyaman untuk anak. Dengan menyekolahkan anaknya di SD Alam subjek berharap sekolah alam mampu menjadi media anak meningkatkan prestasi anak. Subjek juga berharap melalui sekolah alam, anaknya menjadi ulama/ustadz dikemudian hari. Selain itu subjek berharap kedepan sekolah mempunyai stok buku yang banyak, sehingga tidak perlu menunggu pengiriman dari pusat. Subjek berpandangan bahwa Sekolah Alam mempunyai komitmen dalam memberikan pendidikan agama dan pendidikan karakter. Eksplore alam yang menjadi ciri khas dari sekolah alam tersebut, menurut subjek, memiliki keistimewaan sendiri. Seperti belajar di luar kelas (outing classs) dan juga kreatifitas anak sangat di utamakan dalam proses pendidikan.

\section{b. Latar Belakang, Ekspektasi Dan Persepsi Anak Didik terhadap Sekolah Alam Muhamadiyah Banjarbaru}

Sama halnya dengan orangtua, untuk mengetahui latar belakang, ekspektasi dan persepsi anak terhadap Sekolah Alam Muhammadiyah Banjarbaru, peneliti juga menggunakan 5 subjek, yaitu anak yang sekolah di SD Alam Muhammadiyah. Namun, sebagaiama subjek orangtua anak untuk menjaga kerahasiaan subjek, peneliti juga tidak menggunakan nama sebenarnya. Adapun hasil wawancara dan observasi pada masingmasing subjek bisa dijelaskan sebagai berikut: 
1) Subjek Pertama, subjek mengaku bahwa Sekolah Alam adalah pilihan orangtua subjek. Subjek merupakan anak pindahan dari sekolah lain saat naik ke kelas II SD. Subjek mengaku awalnya enggan pindah, karena alasan masih banyak teman di sekolah lama. Sekolah Alam menurutnya sekolah yang seru, karena banyak pelajaran yang menarik, banyak teman dan banyak eksul (subjek ikut Tapak Suci dan Futsal). Terkait dengan teman di lingkungan SD Alam, pandangannya bahwa teman-teman di sekolah ada yang baik dan ada juga yang nakal. Sedangkan guru menurutnya baik semua, seru, tidak pemarah dan menyenangkan. Mata pelajaran yang paling disukai subjek adalah matematika, IPA, IPS, olahraga, dan belajar di luar (eksplore alam dan outing class). Subjek bercita-cita menjadi seperti aya hnya, seorang trainer, banyak ke luar negeri dan banyak ke luar kota.

2) Subjek Kedua, subjek mengaku orangtua subjek lah yang menentukan Sekolah Alam menjadi tempat belajarnya. Menutnya Sekolah Alam adalah sekolah yang seru karena banyak teman, temannya baik walaupun ada juga yang nakal dan suka menolong. Mata pelajaran yang disukai subjek adalah Matematika, IPA dan IPS, PPKN dan khususnya gardening (program menenam). Tentang guru, menurut subjek semua baik dan seru, walaupun ada juga ustadz dan ustadzah yang marah-marah, itupun kalau ada yang nakal. Subjek bercita-cita menjadi koki dan orang kaya.

3) Subjek Ketiga, berbeda dengan subjek sebelumnya subjek ketiga memilih Sekolah Alam karena pilihan sendiri. Subjek mengakui memilih untuk sekolah di SD Alam karena sekolahnya beda dengan sekolah lain, banyak pepohonan, ada arena bermain (outbound) dan kelasnya menarik. Subjek menyampaikan bahwa sekolah di SD Alam sangat menyenangkan, gurunya ramah dan baik, dan pelajarannya asyik. Selain pelajaran di kelas, subjek juga menyukai program-program ekstrakulikuler seperti Tapak Suci dan Hizbul Wathan (Pramuka). Cita-cita subjek ingin menjadi atlit panahan.

4) Subjek Keempat, sama halnya dengan subjek ketiga, sekolah di SD Alam Muhammadiyah atas dasar keinginan sendiri. Menurut pengakuannya orangtuanya termasuk yang memberikan kebebesan kepada anak-anaknya untuk sekolah dimana saja yang diinginkan. Sekolah alam baginya tempat yang menyenangkan, seru dan ramai. Banyak kegiatan yang menarik, seperti tari, outbound dan outing class. Subjek ingin sekali menjadi penari yang berprestasi.

5) Subjek Kelima, subjek adalah anak pindahan dari Australia dan orangtuanyalah yang memilih sekolah untuk subjek. Subjek merupakan keturunan asli orang Indonesia. Namun karena sejak lahir di Australia, subjek memiliki kesulitan dalam berkomunikasi dengan bahasa Indonesia. Sebab itulah, sekolah alam meski dia suka lingkungannya, tapi bagi subjek lingkungannya kurang bersahabat bagi subjek. Karena alasan bahasa subjek belum memiliki teman yang banyak. Subjek terlihat sering menyendiri dan kurang bersosilisasi. Dari wawancara yang penulis lakukan, subjek sebenarnya terbuka, terbukti dalam pengakuaanya subjek juga punya teman dekan, Antusiasme anak-anak yang lain juga besar dengan subjek. Tetapi karena anak-anak yang lain juga punya problem dalam bahasa inggris, sehingga enggan dan memilih mengambil jarak. Subjek memiliki keinginan menjadi guru.

\section{PEMBAHASAN}

Dari beberapa subjek diatas dapat disimpulkan bahwa sebagaimana yang dijelaskan oleh Lutfi Ariefiato (2017:1) bahwa pendidikan alternatif berkembang di 


\section{MADRASAH}

Jurnal Pendidikan dan Pembelajaran Dasar

p ISSN: 1979-5599 | e ISSN: 2502-194X

Page $\mid 47$

Indonesia terjadi karena akibat rasa ketidakpercayaan terhadap sekolah-sekolah formal. Menurutnya, ketidakpercayaan tersebut karena kurikulum yang terus menerus berubah dan memberatkan peserta didik. Anak dianggap sebagai objek bukan subjek, kreatifitas dan kecerdasan anak (Emosional, moral \& spritual) terpasung. Fenomena inilah juga yang penulis dapatkan dari hasil wawancara dengan orangtua kenapa memilih Sekolah Alam dibanding sekolah-sekolah formal. Distrust atau ketidakpercayaan orangtua terhadap sekolah formal inilah yang kemudian membuat orangtua mencari pendidikan alternatif, termasuk sekolah yang berbasis alam.

Distrust atau ketidakpercayaan ini bukan tanpa alasan. Perilaku ini terjadi salah satunya didukung oleh Past Experience atau pengalaman masa lalu. Pengalaman masa lalu bisa saja terjadi tidak secara langsung yang dialami oleh subjek (orangtua). Namun pengalaman masa lalu bisa saja terjadi pada orang-orang terdekat subjek. Pengalaman sebagaimana dijelaskan oleh Valarie (1993;1-2) bahwa hal tersebut merupakan salah satu faktor internal yang mempengaruhi harapan atau keinginan seseorang. Pengalaman masa lalu, baik kita sendiri maupun oranglain, akan sangat menentukan apakah seseorang akan tetap mengunakan jasa atau tidak. "......Past experience, the customer's previous exposure to service that is relevant to the focal service, is another force in shaping predictions and desires (Scott and Yalch 1980; Smith and Swinyard 1983)."Ini sesuai sebagaimana yang diutarakan subjek keempat dalam wawancara:" Tetangga saya memiliki anak ABK dan juga disekolahkan di sekolah formal. Namun, anaknya sering dibully oleh teman-temannya yang lain, guru juga tidak memperlakukan secara khusus sebagaimana harusnya sekolah perlakukan ABK. Bukannya lebih baik, kepribadian anak malah semakin buruk. Oleh karena itulah, saya mending tidak menyekolahkan anak saya ketimbang menyekolahkan tapi kita khawatir....."Orang biasanya, sebelum memutuskan untuk mengunakan pelayanan jasa sebuah lembaga atau perusahaaan, tentu mencari perbandingan dan referensi tentang profil lembaga tersebut. Tidak sedikit pelanggan atau konsumen bertanya ke orang-orang terdekat atapun orang yang pernah menjadi pelanggan. Selain pendapat dan pengalaman diri atau orang lain, peranan promosi pelayanan jasa juga sangat mempengaruhi.

Past Experience, pengalaman tersebut baik ataupun buruk tentang suatu pelayanan, tentu akan sangat mempengaruhi informasi tersebut. Selain itu, di zaman digital saat ini, promosi melalui media (cetak atau elektronik) akan memberi dampak besar, khusus media sosial. Hal Inilah yang disebut Valarie (1993;2) dengan Word of Mouth Communicationts atau mulut ke mulut dan yang disebut Parasuraman dalam Rozalina (2016:131) dengan External Communication atau dikenal dengan sebutan promosi. Parasuraman dalam Rozalina menjelaskan bahwa Word of Mouth Communicationts atau informasi yang didengar melalui teman, tetangga dan orang lain cendrung berperan dalam mempengaruhi latar belakang orangtua dalam mempertimbangan untuk menempatkan anaknya pada sebuah lembaga pendidikan. Jika, informasi tentang yang disampaikan oleh orang lain itu baik, tentu akan sangat besar pengaruhnya bagi orangtua untuk memutuskan. Begitu juga sebaliknya, jika tampilan atau pelayanan jasa yang diterima orang buruk, maka keburukan dan kejelekan pelayanan sebuah jasa akan juga berpengaruh buruk. Ini terlihat dari apa yang disampaikan oleh subjek pertama yang mengatakan: "Pertama saya mengetahui SD Alam Muhammadiyah melalui internet. Selain itu kebetulan tetangga saya terlebih 
dahulu menyekolahkan anaknya di Sekolah Alam. Sehingga kami sering sharing, bertukar pendapat, bertukar pandangan tentang materi apa saja yang diajarkan di sekolah, bagaimana gurunya, bagaimana pelayanan sekolah dan bagaimana jam belajarnya. Dan tetangga saya bilang bahwa sekolahnya baik. Anak-anak tidak hanya melulu belajar di dalam kelas, tapi juga belajar diluar kelas. Sehingga anak-anak tidak hanya bisa belajar menerap ilmu di dalam kelas namun juga mengali ilmu diluar sambil refreshing. Apalagi untuk anak-anak, seperti kelas 1-3, dunia mereka masih banyak bermain......" Fatima Naz (2014:4) memaparkan dalam penelitiannya bahwa dampak dari Word of Mouth yang ditulis orang melalui komentar-komentar di media sosial kebanyakan membuat orang sadar akan pilihannya dan orang akan mencoba meningkatkan atau menghasilkan kualitas yang lebih baik. Ini menunjukkan, bahwa External Communication dan Word of Mouth Communicationts sama sama memberi dampak. "Impact of word of mouth arises duet to social media where people see comments of the people who did shopping from such places".

Selanjutnya latar belakang orangtua menyekolahkan anaknya di SD Alam Muhammadiyah karena faktor Personal Need atau kebutuhan personal. Valarie menyebutkan bahwa personal need juga merupakan faktor yang sangat mempengaruhi berminat tidaknya orang untuk mengunakan pelayanan sebuah lembaga/perusahaan. "Personal needs, states or conditions essential to the physical or psychological well-being of the customer are a second factor that shape desired service Personal needs can fall into many subcategories, including physical, social, and psychological....."

Adapun latar belakang peserta didik dalam mengikuti pendidikan di SD Alam dapat disimpulkan karena dua hal. Latar belakang pertama karena personal need atau dalam hal ini peneliti sebut parent need, dan yang kedua karena school environment. Latar belakang anak dalam menentukan sekolah tidak terlalu berperan banyak. Karena usia mereka masih belum mampu untuk menentukan mana sekolah terbaik dan tidak untuk mereka. Pendidikan usia sekolah dasar masih banyak ditentukan oleh orangtua, karena orangtua masih mendominasi dalam penentuan lembaga pendidikan untuk anak mereka. Sekolah yang dipilih juga berdasarkan keinginan atau kebutuhan orangtua. Ini terlihat dari hasil wawancara kepada peserta didik yang banyak menyatakan bahwa pemilihan sekolah dilakukan oleh orangtua anak. Namun, selain itu peneliti juga menemukan ada anak yang mempunyai orangtua yang cendrung memberikan kebebasan kepada anak untuk memilih sekolah untuk dirinya sendiri. Walaupun, kebebasan tersebut dalam artian masih dalam bimbingan orangtua si anak. Jika pun orangtua memberikan kebebasan tersebut, anak-anak memilih sekolah karena dipengaruhi faktor lingkungan sekolah yang dilihatnya.

Sekolah Alam adalah sekolah yang didesain dengan dipenuhi pepohonan rindang, ruang kelas yang terbuat dari pepohonan dan terbuka, proses belajar yang terjadi di alam terbuka, dan sarana dan prasarana yang terkesan menarik (outbound), yang dalam hal ini peneliti sebut faktor school environment atau among others variables that can affect the teaching-learning process. Latar belakang yang peneliti bahas diatas kemudian dapat disimpulkan bahwa akan mempengaruhi ekspektasi orangtua dalam penentuan pemilihan lembaga pendidikan untuk anak dan juga mempengaruhi persepsi peserta didik dalam proses belajar mengajar. Dari beberapa subjek diatas, dapat disimpulkan bahwa bahwa ada beberapa hal yang melatar belakangi adalah Distrust, Institutional, Word of Mouth Communicationts, Personal Need, Past Experience dan External Communications. 


\section{MADRASAH}

Jurnal Pendidikan dan Pembelajaran Dasar

p ISSN: 1979-5599 | e ISSN: 2502-194X

Page | 49

Ekspektasi atau harapan orangtua menyekolahkan anaknya ke Sekolah Alam dan ekspektasi terhadap sekolah dapat disimpulkan kedalam beberapa hal, yaitu:

a. Anak memiliki pondasi agama yang kuat

b. Anak memiliki kecerdasan sosial

c. Anak memilki moral/karakter/akhlak yang baik

d. Memiliki kemampuan dalam olahraga

e. Sekolah bisa mengarakan anak memiliki bakat tersendiri dan kreatif

f. Suplai Buku

g. SMP dan SMA Alam

Sedangkan ekspektasi peserta didik terhadap SD Alam cendrung tidak variatif, tentu ini karena dasar kebutuhan mereka juga tidak banyak. Sehingga dapat disimpulkan hanya dua: Program Ekstrakurikuler diperbanyak dan Program Pengembangan Kemandirian Siswa lebih sering dilaksanakan. Menariknya dari semua wawancara peneliti terhadap orangtua anak didik peneliti tidak menemukan satu pun subjek yang menyinggung tentang harapannya pada aspek akademik atau kognitif anak.

Adapun persepsi orangtua mengenai SD Alam Muhammadiyah, dapat dilihat sebagai berikut:

a. Konsep sekolah berbasis alam yang menyenangkan dan menarik untuk anak (Educational System)

b. Porsi agama lebih banyak (Religiusitas)

c. Peraturan lebih fleksibel dibanding sekolah negeri

d. Mengutamakan nilai agama, karakter dan kreatifitas.

e. Tidak membedakan status sosial dan kondisi anak

Adapun persepsi anak (peserta didik) terhadap SD Alam Muhammadiyah cendrung sama dan tidak bervariatif, diantaranya adalah:

a. Sekolah, Guru dan Mata Pelajaran menyenangkan

b. Banyak Ekstrakurikuler

\section{KESIMPULAN}

Berdasarkan penyajian dan hasil analisis data maka dapat disimpulkan bahwa latar belakang orangtua menyekolahkan anaknya karena beberapa hal yaitu (1) Distrust; (2) Past Experience; (3) Word of Mouth Communicationts; (4) External Communications; (5) Personal Need; (6) Institutional. Sedangkan latar belakang peseerta didik sekolah di SD Alam karena alasan (1) Parent Need, (2) School Environment.

Adapun ekspektasi atau harapan orangtua adalah : (1) Anak memiliki pondasi agama yang kuat; (2) Anak memiliki kecerdasan sosial; (3) Anak memilki moral/karakter/akhlak yang baik; (4) Memiliki kemampuan dalam olahraga; (5) Sekolah bisa mengarakan anak memiliki bakat tersendiri dan kreatif; (6) Suplai Buku yang tersedia dan (7) Pembangunan SMP dan SMA Alam.

Sedangkan eksepektasi peserta didik yaitu (1) Program Ekstrakurikuler diperbanyak (2) Program Pengembangan Kemandirian Siswa lebih sering dilaksanakan. Sedangkan pada aspek persepsi orangtua dapat disimpulkan yaitu (1) Konsep sekolah berbasis alam yang menyenangkan dan menarik untuk anak; (2) Porsi agama lebih banyak; (3) Peraturan lebih fleksibel dibanding sekolah negeri; (4) Mengutamakan nilai agama, karakter dan kreatifitas dan tidak membedakan status sosial dan kondisi anak. 
Sedangkan persepsi anak ialah sekolah, guru dan mata pelajarannya menyenangkan dan banyak ekstrakurikuler.

\section{E. SARAN}

Berdasarkan hasil penelitian ini, terdapat beberapa hal yang menjadi implikasi akademik antara lain:

1. Berdasarkan penelitian ini menguatkan bahwa Sekolah Alam dan metode pembelajaran yang digunakan merupakan metode alternatif yang belakangan semakin digandrungi oleh orangtua dalam memberikan pendidikan untuk anak didik. Penelitian ini juga menjadi penting untuk para pengambil kebijakan dan para pendidik untuk memperbaiki sistem atau metode pembelajaran di daerah atau di Indonesia secara umum atas menurunnya kepercayaan orangtua terhadap pendidikan-pendidikan formal-tradisional

2. Penelitian ini juga diharapkan menjadi perhatian untuk pengelola SD Alam Muhammadiyah Banjarbaru bahwa pelayanan jasa (produk pendidikan yang diberikan) yang baik akan sangat mempengaruhi meningkatnya penguna jasa layanan sekolah. Karena Past Experience atau pengalaman orangtua yang menerima pelayanan jasa dari sekolah akan mempengaruhi calon-calon orangtua yang akan menjadi konsumen dan itu sangat besar dipengaruhi melalui Word of Mouth Communications (mulut ke mulut).

3. Peneliti juga memberikan masukan kepada SD Alam Muhammadiyah untuk terus melakukan promosi yang lebih baik melalui media-media yang menjadi konsumsi masyarakat luas, sebab external communication merupakan faktor yang berperan penting.

4. Peneliti juga menyarankan SD Alam Muhammadiyah sudah saatnya untuk perlahan menyiapkan diri menjadi sekolah yang berstandar internasional. Paling tidak SD Alam Muhammadiyah mendesain kembali kurikulum dan ekskul dengan memasukan konten yang mengakomodasi kebutuhan siswa asing.

\section{REFERENSI}

Ariefianto, L. (2017). Homeschooling: Persepsi, Latar Belakang dan Problematikanya (Studi Kasus pada Peserta Didik di Homeschooling Kabupaten Jember) (Homeschooling: Perception, Background and Problematic (Case Study in Student Homeschooling District of Jember)). JURNAL EDUKASI, IV(2), 21-26.

Arikunto, S. (2010). Prosedur Penelitian Suatu Pendekatan Praktik. Jakarta: PT. Rineka Cipta. Arikunto, S. (2013). Dasar-Dasar Evaluasi Pendidikan: Edisi 2. Jakarta: Bumi Aksara.

Askar, N., Rohmad, Z., \& MH., S. (n.d.). Harapan Orang Tua dalam Menyekolahkan Anak di Pendidikan Al-Irsyad Al-Islamiyyah Pemalang (Studi Deskriptif Kualitatif pada SD AlIrsyad Al-Islamiyyah Pemalang Tahun Pelajaran 2015/2016). 3-15.

Basir, A., \& Ramadan, W. (2017). Pembentukan Karakter Kepemimpinan Siswa Melalui. Jurnal Muadalah, IV(1), 1-14. Retrieved from http://jurnal.uinantasari.ac.id/index.php/psj/article/view/2118/1540

Chaplin, J. P. (2011). Kamus Lengkap Psikologi. Jakarta: Rajawali Press.

Creswell, J. W. (2013). Penelitian Kualitatif dan Desain Riset; Memilih di Antara Lima Pendekatan. Yogyakarta: Pustaka Pelajar. 


\section{MADRASAH}

Jurnal Pendidikan dan Pembelajaran Dasar

p ISSN: 1979-5599 | e ISSN: 2502-194X

Page $\mid 51$

Elfindri, \& dkk. (2012). Pendidikan Karakter Kerangka, Metode dan Aplikasi untuk Pendidik dan Profesional. Jakarta: Baduose Media Jakarta.

Hadziq, A. (2016). Pembelajaran Agama dan Lingkungan dalam Kultur Sekolah Alam (Membumikan Kesadaran Lingkungan Sejak Dini). Tadris, 11(1).

HS, M. N. (1997). Himpunan Istilah Psikologi. Jakarta: CV. Pedoman Ilmu Jiwa.

Hurlock, E. B. (n.d.). Psikologi Perkembangan Suatu Pendekatan Sepanjang Rentang Kehidupan (Kelima). Jakarta: Penerbit Erlangga.

Maryati. (2017). Sekolah Alam, Alternatif Pendidikan Sains yang Membebaskan dan Menyenangkan. Prosiding Seminar Nasional Penelitian, Pendidikan Dan Penerapan MIPA, Yogyakarta: UNY.

Naz, F. (2014). Word of Mouth and Its Impact on Marketing. 4(1), 4.

Novianty, R., Sugiyanto, L., \& Mala, I. W. (2016). Ekspektasi Dan Persepsi Mahasiswa Terhadap Kualitas Pendidikan Pada Universitas Soerjo Ngawi. Ekuilibrium : Jurnal Ilmiah Bidang Ilmu Ekonomi, 11(2), 131-140. https://doi.org/10.24269/ekuilibrium.v11i2.212

Purnamasari, I. (2017). Homeschooling dalam Potret Politik Pendidikan: Studi Etnografi pada Pelaku Homeschooling di Yogyakarta. 12.

Sari, R. R., Supriyanto, A., \& Zulkarnain, W. (n.d.). Persepsi dan Ekspektasi Orang Tua Peserta Didik Tentang Mutu Pendidikan Berkaitan Dengan Kepercayaannya Terhadap SDN Purwodadi 03 Kecamatan Purwodadi Kabupaten Pasuruan.

Siregar, N. S. S. (2013). Persepsi Orang Tua terhadap Pentingnya Pendidikan bagi Anak. Jurnal Ilmu Pemerintahan Dan Sosial Politik, 1(1), 11-27.

Sugiyono. (2010a). Metode Penelitian Pendidikan. Bandung: Alfabeta.

Sugiyono. (2010b). Metode Penelitian Pendidikan Pendekatan Kuantitatif, Kualitatif, dan RED. Bandung: Penerbit Alfabeta Bandung.

Wibowo, A. (2012). Pendidikan Karakter; Strategi Membangun Karakter Bangsa Berperadaban. Yogyakarta: Pustaka Pelajar.

Yusuf, S. (2011). Psikologi Perkembangan Anak dan Remaja. Bandung: PT. Remaja Rosdakarya.

Zeithaml, V. A., Berry, L. L., \& Parasuraman, A. (1993). The Nature and Determinants of Customer Expectations of Service. Journal of the Academy of Marketing Science, 21(1), 1-12. https:// doi.org/10.1177/0092070393211001 